\title{
Integrating the Social Interaction System of Dalihan Na Tolu into the Problem Based Learning on Biology Subjects to Increase Students' Achievement
}

\author{
Widya Arwita ${ }^{1,2}$, Mohamad Amin ${ }^{3}$, Herawati Susilo ${ }^{3}$, Siti Zubaidah ${ }^{3}$ \\ ${ }^{1}$ Doctoral Program of Biology Education, Universitas Negeri Malang, Jalan Semarang 5 Malang, East Java, Indonesia 65145 \\ ${ }^{2}$ Biology Department, Universitas Negeri Medan, Jalan Willem Iskandar Pasar V Medan, North Sumatera, Indonesia 20221 \\ ${ }^{3}$ Biology Department, Universitas Negeri Malang, Jalan Semarang 5 Malang, East Java, Indonesia 65145
}

\begin{abstract}
This research was expanded research which aimed to develop problem based learning model by social interaction system of Dalihan Na Tolu to increase the students' achievement. It used approach of Plomp res earch design which consisted of three steps, they were the first research, prototype, and assessment. The product was the model of problem based learning of Dalihan Na Tolu system (PBL DNT) that valid, practice, and effective. The result of the research showed that the model of PBL DNT was valid which the content validity was 4,70 and the construct validity was 4,94. The implementation of the model of the first trial and the second one that observed by two observers was done well. The effectivity test was done by analyzing the test result of students' cognitive ability in Biology. The test result of the first trials was $71 \%$ students classically got the graduation criteria.
\end{abstract}

Keywords: Problem based learning, Biology learning, Dalihan Na Tolu, Model of learning, research design, learning through culture

\section{Introduction}

The reshuffle of education paradigm happened when facing the $21^{\text {st }}$ century, so that the students had to been prepared by skill which needed in working environment in this country (NCREL \& Metiri Group, 2003). One of the skill was having scientific literary, it about the knowledge and the understanding about the scientific concept and the process which needed to take the individual decision, participate in social and culture, and also economic productivity (Turiman, 2012). It meant, the education might be able to prepare the students as human resources (SDM) who competent in solving contextual problem and the more complex one, however, it still could as a fort for the negative impact by keeping the prestige of country. Education couldn't be separated from Indonesian culture, therefore, integrating the values of culture with the learning of $21^{\text {st }}$ century would having potency for building the way of thinking in global but working in local.

The survey result which was reported by Arwita (2016) showed that a large part of Biology teachers in SMA Negeri Kota Tebing Tinggi used the direct instruction model. It seemed that $37,5 \%$ of teachers' answers about process of Biology learning was asking and answering method and making big group discussion. Therefore, it could be concluded that the learning which had done wasn't trigger the students to study actively. Arends (2013) said that the weakness of direct instruction model just oriented to deliver information and the teacher was the most active in transferring information. Learning process using direct instruction couldn't answer the learning demands which made students could build their knowledge and developed their scientific process in themselves.

The Partnership for $21^{\text {st }}$ Century Learning (2015) suggested the problem based learning as one of learning model which could be applied in preparing students so that they could build the essential skill in $21^{\text {st }}$ century. The problem based learning asked students to find their problems and the problems solving authentically by themselves. Arends, (2013) also said that the problem based learning served the situation of authentic problem and having meaningful for students was the base of the investigation and inquiry. Scientific process been the strong character in problem based learning, because according to Paidi (2012) somebody who wanted to answer his curiosity about the nature, he might through logic step such as observation, identification of problem till investigation for solving problem. The survey result which done by writers showed that Biology teachers in SMA Negeri Kota Tebing Tinggi weren't used PBL model yet. It happened because some reasons like the teachers didn't understand about PBL yet and the time which used was less efficient so that the teachers took the save way like direct instruction model in transferring the subject material so that the curriculum could be reached.

The difficulty of the teachers and students in doing PBL could be solved by integrating the learning process and social interaction activity in around of society. The steps had been adapted with the condition or students' environment. Most of the learning model which were applied nowadays used foreign learning system so it made a difficulty in adapting the application in local classes. Culture of a place could influence somebody activity and their way of thinking. It also said by Sardjiyo \& Pannen (2008) that the learning based on culture made possible for teachers and students to participate actively according to the culture which they known so could get the optimal result of learning.

Tebing Tinggi city was in North Sumatera province, Indonesia, which one of the tribes that dominate was 


\section{International Journal of Science and Research (IJSR) \\ ISSN (Online): 2319-7064}

Index Copernicus Value (2015): 78.96 Impact Factor (2015): 6.391

Bataknese. Bataknese had a philosophy in solving a problem in their society. It was known Dalihan $\mathrm{Na}$ Tolu, it meant three feet fireplace. Dalihan Na Tolu was social interaction system in Batak society. It's often used when there was a problem in a family or society through discussion (Manik, 2015). According to the name, three feet fireplace, this social interaction system consisted of three groups of society, they were hula-hula, dongan tubu, and boru. All the groups had role each other, so this system could be applied in learning process in class.

The grouping of students in model of problem based learning could be expanded to be a smaller group such as in DNT interaction system. So, a group was divided into three subgroup, they were hula-hula group, dongan tubu, and boru. According to Griffiths (2013), the students who involved in small groups could help themselves in developing intellectual ability or personality. The process of building and managing a group, and also helping a relationship could give a useful learning experience for students' understanding and knowledge, their participation, sense of belonging, and involvement of students in group.

The application of the social interaction system of DNT in the learning previously done by Sinaga (2007) in which the formation of DNT is one stage in developing a learning model for learning mathematics. Biology has different characteristics with mathematics. Biology is part of the science that has four basic components such as processes, products, attitudes, and technology so that the learning process is important to have these basic components (Carin, 1997). Learning Biology would be meaningful if there was relationship between the material and the process of learning with the local wisdom of the students because the students would be easier to apply the lesson and to use their knowledge in their daily. Based on description above and the characteristics of the biological study, researchers tried to develop problem based learning model by integrating the social system DNTdari Batak's culture.

\section{The Aim of the Study}

This research aimed to test the quality of model PBL DNT they were validity, practicality, and effectiveness.

\section{The Research Method}

This research was design research which development the problem based learning of DNT system on Biology. The expanded model which was used was referred to research design by Plomp (2007). The step of this research was prototyping phase (prototype), and assessment phase (assessment). This article was limited in discussing two steps only, they were prototype and assessment. Qualitty of the learning model that has been developed viewed from three aspects by Nieveen (1999), i.e. validity, practicality, and effectiveness.

\subsection{Research Design}

PBL DNT model that had been designed was done the measurement about the validity model and the item of the lesson by four validation experts, they were one expert of learning model, one expert of Biology subject matter, and two Biology teachers as the actors. The assessment step was done for knowing the practicality and the effectiveness of the PBL DNT learning model. The practicality of the model was valued from the application of PBL DNT model through trials implication in the class, meanwhile the effectiveness was valued from the result of students' cognitive learning who followed the trials class. The trials was done at least twice to reach the practicality or effectiveness criteria.

\subsection{The Data and the Instrument of Collecting Data}

The step of prototype data were qualitative data from the result of validation sheets, meanwhile the step of assessment data were qualitative and quantitative. Qualitative data were the result of observation of learning application by observer, meanwhile the quantitative data were gotten from the students' cognitive achievement. The instrument of collecting data of the research and the expanding were in Table 1.

Table 1: The instrument of collecting data

\begin{tabular}{|c|c|c|c|}
\hline No & Expanding Step & $\begin{array}{l}\text { Kinds of } \\
\text { Instrument }\end{array}$ & Function \\
\hline 1 & $\begin{array}{l}\text { Prototype Step } \\
\text { Validity of PBL DNT } \\
\text { model } \\
\text { a. Validation of expert } \\
\text { of learning model } \\
\text { b. Validation of expert } \\
\text { of Biology subject } \\
\text { matter }\end{array}$ & $\begin{array}{l}\text { a. Validation sheet } \\
\text { b. Validation sheet }\end{array}$ & $\begin{array}{l}\text { Knowing the } \\
\text { validity of } \\
\text { PBL DNT } \\
\text { model }\end{array}$ \\
\hline 2 & $\begin{array}{l}\text { Assessment Step } \\
\text { - The practicality of } \\
\text { PBL DNT model } \\
\text { The application of } \\
\text { PBL DNT model } \\
\text { - The effectiveness of } \\
\text { PBL DNT } \\
\text { The result of } \\
\text { cognitive learning }\end{array}$ & $\begin{array}{l}\text { Observation } \\
\text { sheet of learning } \\
\text { application } \\
\text { Test of the result } \\
\text { of cognitive } \\
\text { learning ability }\end{array}$ & $\begin{array}{l}\text { Knowing the } \\
\text { practicality } \\
\text { of PBL DNT } \\
\text { model } \\
\text { Knowing the } \\
\text { effectiveness } \\
\text { of PBL DNT } \\
\text { model. }\end{array}$ \\
\hline
\end{tabular}

\subsection{The Analyzing of Data}

The prototype step was the step of validation of PBL DNT model by expert and was analyzed by descriptive quantitative. The analyzing of validity test used Likert scale (1-5) by following category of model validity by Hobri (2009) in Table 2.

Table 2: The Validity Category of PBL DNT model

\begin{tabular}{|l|l|}
\hline \multicolumn{1}{|c|}{ Coefficient } & \multicolumn{1}{c|}{ Category } \\
\hline $1,00 \leq \mathrm{Va}<2,00$ & Invalid \\
\hline $2,00 \leq \mathrm{Va}<3,00$ & Less of valid \\
\hline $3,00 \leq \mathrm{Va}<4,00$ & Valid enough \\
\hline $4,00 \leq \mathrm{Va}<5,00$ & Valid \\
\hline $\mathrm{Va}=5$ & Very valid \\
\hline
\end{tabular}




\section{International Journal of Science and Research (IJSR) \\ ISSN (Online): 2319-7064}

Index Copernicus Value (2015): 78.96 | Impact Factor (2015): 6.391

According to the scale above so, the validity result could be declare suitable if gotten the modus with the score 3,00-5,00, meanwhile the modus result with the score 1,00-2,99 were needed revision. The assessment step which had been done was to see the practicality and effectiveness of PBL DNT model in class. The practicality was gotten from observation data of application model. The application test was done by looking the value of average of application model through two observers, by the interpretation criteria by Maimunah (2016) in Table 3.

Table 3: The Application Criteria of PBL DNT Model

\begin{tabular}{|l|l|}
\hline \multicolumn{1}{|c|}{ Application Criteria $(\mathrm{T})$} & \multicolumn{1}{c|}{ Criteria } \\
\hline $\mathrm{T}<1,5$ & Un carried out \\
\hline $1,5 \leq \mathrm{T}<2,5$ & A little part of carried out \\
\hline $2,5 \leq \mathrm{T}<3,5$ & A large of carried out \\
\hline $3,5 \leq \mathrm{T} \leq 4$ & All carried out \\
\hline
\end{tabular}

The analyzing data for effectiveness test was done by making score tabulation and cognitive learning result which done by students. Next, the students' cognitive achievement was categorized according to criteria of students' appraisal which adopted from Hobri (2009) in Table 4. The criteria of learning model was affective if the result of study $80 \%$ of students classically in minimum, medium and maximum category.

Table 4: The Result Criteria of Students' Cognitive Learning

\begin{tabular}{|c|c|}
\hline Students' Score & Criteria \\
\hline $0 \leq \mathrm{HBK}<40$ & Lowest \\
\hline $40 \leq \mathrm{HBK}<60$ & Low \\
\hline $60 \leq \mathrm{HBK}<75$ & Medium \\
\hline $75 \leq \mathrm{HBK}<90$ & High \\
\hline $90 \leq \mathrm{HBK}<100$ & Highest \\
\hline
\end{tabular}

\section{Results}

\section{The Result of Prototype Step}

The prototype step was the expanding step of model of learning based on problem of DNT system. Prototype step aimed to see the validity of PBL DNT model. Syntax of PBL DNT which arranged consisted of 6 steps they were, (a) Making group and sub group of DNT; (b) guideline students on actual and authentic problem; (c) problem solving with the system of DNT; (d) giving scaffolding to students; (e) presentation of problem solving result; (f) taking decision, analyzing and solving problem evaluation. This model was tested about the validity by an expert of learning model and an expert of Biology subject matter. The appraisal of model book was done to get the validity of PBL DNT model. The data of result of content validity could be seen in Table 5 . Validation data which gotten showed that PBL model was valid.

Table 5: The summary of data of validation result of PBL DNT model

\begin{tabular}{|c|l|c|c|c|}
\hline \multirow{2}{*}{ No } & \multicolumn{1}{|c|}{ Aspect } & \multicolumn{2}{|c|}{$\begin{array}{c}\text { Validation } \\
\text { scale }\end{array}$} & \\
\cline { 3 - 4 } & & 1 & 2 & \\
\hline 1 & Supporting theory & 5,00 & 5,00 & 5,00 \\
\hline 2 & Syntax & 4,75 & 4,50 & 4,63 \\
\hline 3 & Social system & 5,00 & 4,20 & 4,60 \\
\hline
\end{tabular}

\begin{tabular}{|l|l|l|l|l|}
\hline 4 & Principle of management reaction & 4,67 & 5,00 & 4,83 \\
\hline 5 & Supporting system & 5,00 & 4,25 & 4,63 \\
\hline 6 & $\begin{array}{l}\text { Instructional impact and escort } \\
\text { impact }\end{array}$ & 4,50 & 4,50 & 4,50 \\
\hline \multicolumn{3}{|c|}{ The total of validity of PBL DNT model } & $\mathbf{4 , 7 0}$ \\
\hline
\end{tabular}

\section{Assessment Step Result}

Assessment step aimed to see the practicality and effectiveness of learning model. The practicality of this research could be seen from the application range of PBL DNT model in trials class, meanwhile the effectiveness of PBL DNT model aimed to see how far the effectiveness of the model in increasing the students' achievement

a. The result of application analyzing of PBL DNT model The appraisal of model application was seen from 4 aspects they were, (1) application of syntax, (2) social system application, (3) Application of principle of management reaction, and (4) supporting system. The application of PBL DNT model was observed by two observers and was done twice trials, where for each trials consisted of 4 meeting. The average of the result of appraisal observation of PBL DNT model in first trials was in table 7 below.

Table 7: The average of appraisal of PBL DNT model in first trials

\begin{tabular}{|c|c|c|c|c|c|}
\hline \multirow{2}{*}{ Value Aspect } & \multicolumn{4}{|c|}{ Meeting } & \multirow{2}{*}{ Meeting average } \\
\hline & I & II & III & IV & \\
\hline A & 2,67 & 3,00 & 3,33 & 3,42 & 3,10 \\
\hline B & 3,00 & 3,00 & 3,25 & 3,25 & 3,13 \\
\hline $\mathrm{C}$ & 3,25 & 3,25 & 3,38 & 3,50 & 3,34 \\
\hline $\mathrm{D}$ & 4,63 & 4,63 & 4,88 & 4,88 & 4,75 \\
\hline \multicolumn{5}{|c|}{ Total average } & 3.58 \\
\hline
\end{tabular}

Explanation:

A: Application of syntax

B: Application of social system

C: Application of principle of management reaction

D: supporting system

According to the observation result of PBL DNT model in first trials, it was gotten the level of appraisal of PBL model totality for large amount was carried out. Second trials was done to see weather any increasing of application of PBL DNT model been better or vice versa.

Table 8: The average of Application of PBL DNT model in second trials

\begin{tabular}{|c|c|c|c|c|c|}
\hline \multirow{2}{*}{$\begin{array}{l}\text { Value } \\
\text { aspect }\end{array}$} & \multicolumn{4}{|c|}{ Meeting } & \multirow{2}{*}{$\begin{array}{l}\text { Meeting } \\
\text { average }\end{array}$} \\
\hline & I & II & III & IV & \\
\hline $\mathrm{A}$ & 4,50 & 4,25 & 4,33 & 4,42 & 4,38 \\
\hline B & 4,17 & 4,42 & 4,50 & 4,58 & 4,42 \\
\hline $\mathrm{C}$ & 4,25 & 4,50 & 4,13 & 4,75 & 4,41 \\
\hline $\mathrm{D}$ & 5,00 & 5,00 & 5,00 & 5,00 & 5,00 \\
\hline \multicolumn{5}{|c|}{ Total average } & 4,55 \\
\hline
\end{tabular}

Explanation:

A: Application of syntax

B: Application of social system

C: Application of principle of management reaction

D: supporting system

The result of appraisal of PBL DNT model based on Table 8 showed that the appraisal level had fulfilled whole criteria had carried out. The raising of appraisal of PBL DNT model 


\section{International Journal of Science and Research (IJSR) \\ ISSN (Online): 2319-7064 \\ Index Copernicus Value (2015): 78.96 Impact Factor (2015): 6.391}

in first trials and second trials could be seen in Figure 1 below.

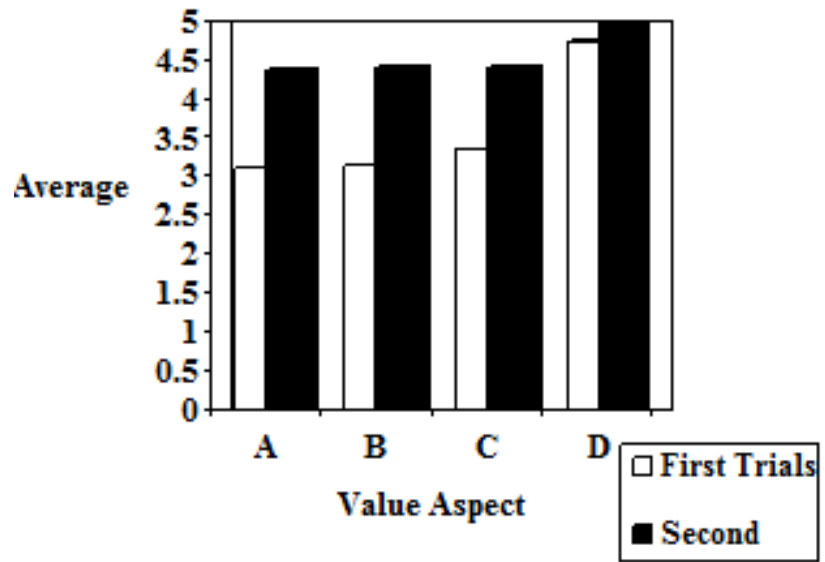

Figure 1: The level of Application of PBL DNT model

\section{Explanation:}

A: Application of syntax

B: Application of social system

C: Application of principle of management reaction

D: supporting system

\section{b. The result of Analyzing the Increasing of Students' Cognitive Achievement}

The test of Effectiveness was done by looking the increasing of learning result, it was students' cognitive ability after followed PBL DNT program. The test of result of cognitive learning was done for 38 students. The test was done twice for each trials, trials $1^{\text {st }}$ and trials $2^{\text {nd }}$. Giving test had done every the end of trials. The data conclusion of the result of students' cognitive learning in first trials could be seen in Table 9 .

Table 9: The achievement students' cognitive in first trials

\begin{tabular}{|c|c|c|c|}
\hline Students' score & Criteria & F & $\%$ \\
\hline $0 \leq \mathrm{HBK}<40$ & Lowest & 0 & 0 \\
\hline $40 \leq \mathrm{HBK}<60$ & Low & 11 & 29 \\
\hline $60 \leq \mathrm{HBK}<75$ & Medium & 5 & 13 \\
\hline $75 \leq \mathrm{HBK}<90$ & High & 20 & 53 \\
\hline $90 \leq \mathrm{HBK}<100$ & Highest & 2 & 5 \\
\hline
\end{tabular}

The achievement of students' cognitive in first trials was $71 \%$ students in medium criteria, and $29 \%$ students in low criteria. These data showed that PBL DNT model wasn't fulfilled the effectiveness criteria through the result of students' cognitive learning. The result of students' cognitive learning in second trials could be seen in Table 10 .

Table 10: The achievement of students' cognitive in Second trials

\begin{tabular}{|c|c|c|c|}
\hline Students' score & Criteria & F & $\%$ \\
\hline $0 \leq \mathrm{HBK}<40$ & Lowest & 0 & 0 \\
\hline $40 \leq \mathrm{HBK}<60$ & Low & 3 & $8 \%$ \\
\hline $60 \leq \mathrm{HBK}<75$ & Medium & 8 & $21 \%$ \\
\hline $75 \leq \mathrm{HBK}<90$ & High & 18 & $47 \%$ \\
\hline $90 \leq \mathrm{HBK}<100$ & Highest & 9 & $24 \%$ \\
\hline
\end{tabular}

The data in the table showed any increasing; it was $92 \%$ students in medium criteria. It showed that PBL DNT model had been fulfilled effectiveness criteria through the result of cognitive learning ability.

\section{Discussion}

The learning model consists of several components, such as learning structure or syntax, social systems, roles / tasks of teachers also called reaction principle management, support systems, and the impact of instructional and impact accompanist (Joyce, Weil \& Calhoun, 2011), so that to develop a model of learning must pay attention to these components. The development of problem based learning model with DNT system generating syntax consists of six stages, i.e.: (1) The establishment of groups and sub-groups of DNT; (2) Directing students on the issue of actual and authentic; (3) Problem solving with DNT system; (4) gives scaffolding to students, (5) Presentation of the results of solving the problem, and (6) Decision-making, analysis and evaluation of problem solving. The social system of the model PBL DNT is a form of the role of teachers and students in the classroom. Teachers and students actively participate so it many ideas that will be discussed with each other. Teachers can help develop the intellectual abilities mental processes of students, and have the freedom in an open discussion so that they engage in creative problem solving.

Reaction principle in the management of DNT PBL models that teachers manage classroom give optimum instruction with the right timing, monitoring and guiding how students raise issues / ideas and process information to find a solution. Teachers also gave support to the psychological conditions that allow students to build a creative response.

Support system of PBL DNT's models is the learning device such as syllabus, lesson plan and sheet of student activity. Application of learning models are not only supported by the learning device but also supported by evaluation tools.

Impact instructional on the model PBL DNT is students can achieve the competencies expected by the learning material such as mastery of concepts, ability to students interact, and attitudes are formed from the social system of interaction in learning, such as responsibility, cooperation, mutual respect, mannered, and so on. Accompanist impact of PBL DNT model is expected to form students' independence, cooperative spirit, in the comfort of opinion. This impact is also similar with the findings of an increase in interintrapersonal ability students through the integration of local cultural values in the learning (Wardani, Kadarohman, Buchari, \& Permanasari, 2013).

The achievement of students' cognitive gained by giving tests to students in the form of an essay on each trial PBL DNT models. Based on the results obtained, there is an increase in cognitive learning outcomes in the second trials of PBL DNT models. PBL-DNT can increase students' cognitive achievement, which can be seen from the learning process has been applied. Students are trained to cooperate in finding problems and the solution through the groups and subgroups that have their respective roles as the life Batak society in solving problems. Culture in this case Dalihan na tolu has a

\section{Volume 6 Issue 1, January 2017}




\section{International Journal of Science and Research (IJSR) \\ ISSN (Online): 2319-7064}

Index Copernicus Value (2015): 78.96 | Impact Factor (2015): 6.391

role in improving student learning outcomes, as well as Gilbert (2011) stated that other than cultural-based education can revitalize and preserve the native language and culture can also improve students' academic achievement.

\section{Conclusion}

PBL DNT was a learning model which integrating the system of Batakness social interaction of Dalihan $\mathrm{Na}$ Tolu into problem based learning. The syntax of PBL DNT model which had expanded consisted of 6 step, they were (1) making group and sub group of DNT; (2) guideline students on actual and authentic problem; (3) problem solving with the system of DNT; (4) giving scaffolding to students; (5) presentation of problem solving result; (6) taking decision, analyzing and solving problem evaluation. The result of the research showed that PBL DNT model had good quality. PBL DNT model had fulfilled product criteria which valid, simple, and affective through the students' cognitive achievement.

\section{References}

[1] Arends, R. I. 2013. Belajar untuk Mengajar. Terjemahan Made Frida Yulia. Jakarta: Salemba Humanika.

[2] Arwita, W., Amin, M., Susilo, H., \& Zubaidah, S. 2016. Profil Pembelajaran Biologi di SMA Negeri Kota Tebing Tinggi. Makalah disajikan dalam Seminar Nasional Ke 3 Biologi, IPA, dan Pembelajarannya, Jurusan Biologi FMIPA UM, Malang, 15 Oktober.

[3] Carin, AA. 1997. Teaching Modern Science. (7 th Edition). New Jersey: Merril Publishing Company.

[4] Gilbert, W.S. (2011) Cite as from J. Reyhner, W.S. Gilbert \& L. Lockard (Eds.). Honoring Our Heritage: Culturally Appropriate Approaches for Teaching Indigenous Students (pp. 43-55). Flagstaff, AZ: Northern Arizona University.

[5] Hobri. 2009. Metode Penelitian Pengembangan (Aplikasi pada Penelitian Pendidikan Matematika). Jember: Universitas Jember.

[6] Joyce, Weil, \& Calhoun. 2011. Models of Teaching (Model-model Pengajaran). Yogyakarta; Pustaka Pelajar.

[7] NCREL \& Metiri Group. 2003. enGauge 21st century skills : Literacy in the digital age. http://www.ncrel.org/engauge.org [1 April 2012].

[8] Paidi. 20 12. Biologi, Sains, Lingkungan dan Pembelajarannya dalam Upaya Peningkatan Karakter Siswa. Makalah disajikan dalam Seminar Nasional IX Pendidikan Biologi, Universitas Negeri Sebelas Maret, Surakarta, 7 Juli 2012. Dalam Portalgaruda database, (Online), (http://id.portalgaruda.org/), diakses 29 September 2016.

[9] Plomp, T. 2007. Educational Design Research: An Introduction to Educational Design Research. Enschede, Netherland: National Intitute for Curriculum Development.

[10] Sardjiyo \& Pannen, P. 2008. Pembelajaran Berbasis Budaya. Dalam Wahab, A. A. (ED), Pembaharuan dalam Pembelajaran PKN. (hal. 4.1-4.55). Jakarta: Universitas Terbuka.

[11] Sinaga, B. 2007. Pengembangan Model Pembelajaran Matematika Berdasarkan Masalah Berbasis Budaya Batak. Disertasi tidak diterbitkan. Surabaya: Universitas Negeri Surabaya.

[12] The Partnership for $21^{\text {st }}$ Century Learning. 2015. P21 Framework Definitions. (Online), (www.p21.org), diakses 08 Oktober 2016

[13] Turiman, P., Omar, J., Daud, A. M., \& Osman, K. 2012. Fostering the 21st Century Skills through Scientific Literacy and Science Process Skills. Procedia - Social and Behavioral Sciences: 110-116. (Online) (www.sciencedirect.com). diakses 18 Agustus 2012.

[14] Wardani, S., Kadarohman, A., Buchari, \& Permanasari, A. 2013. Java Culture Internalization in Elektrometri Learning Based Inquiry Laboratory Activities to Increase Inter-Intrapersonal Intelligence. International Journal of Science and Research: 417-421. (Online), (https://www.ijsr.net/archive/v2i5/IJSRON2013930.pdf) diakses 05 Januari 2017. 